NBER WORKING PAPER SERIES

TESTING FOR CONTRACTING EFFECTS ON EMPLOYMENT

Mark Bils

Working Paper No. 3051

NATIONAL BUREAU OF ECONOMIC RESEARCH

1050 Massachusetts Avenue

Cambridge, MA 02138

July 1989

I thank David Weil, Henry Farber, and Beverly Hirtle for help in obtaining data on labor bargaining dates. I am grateful for helpful comments from Robert Barro, Adrian Pagan, David Romer, and John Taylor. This paper is part of NBER's research program in Economic Fluctuations. Any opinions expressed are those of the author not those of the National Bureau of Economic Research. 
NBER Working Paper \#3051

July 1989

\title{
TESTING FOR CONTRACTING EFFECTS ON EMPLOYMENT
}

\begin{abstract}
I test the importance of wage rigidities from long-term contracts by observing how employment behaves when firms and workers recontract. If rigidities are important then we should observe employment adjusting after recontracting to undo movements in employment during the past contract that were excessive due to rigid wages.

The data are for twelve manufacturing industries that display a strong bargaining pattern.

I find that contract rigidities are important, causing considerably larger fluctuations in employment than would occur with flexible wages. By far the most striking case is in motor vehicles where long-term contracts much more than double the size of fluctuations in employment. I also examine the behavior of wage rates when new contracts are introduced. Wage growth does respond to employment growth during the prior contract in several of the industries; but these responses are not related to the pattern of employment responses across industries.
\end{abstract}

Mark Bils

Hoover Institution

Stanford University

Stanford, CA 94305 
In many models of macro fluctuations wage rigidities no longer play a central role. The most obvious examples are real business cycle models (e.g., Prescott, 1986). which not only assume employment equates supply and demand, but also typically ignore matching model predictions for real wage movements to actual data. More striking, however, is that those at tempting to explain fluctuations with the aid of various market fallures have greatly reduced the emphasis on wage rigidities. I note in particular the comments of Rotemberg (1987), Summers (1987), and Lindbeck and Snower (1987).

This deemphasis can be largely traced to the implicit labor contracting literature of the 1970's. This literature typically separated the decisions for employment and compensation, and arrived at efficient cyclical choices for employment independently of the cyclical pattern of wage rates. Barro (1977) pointed out the incompatibility of traditional rigid rage models with the then burgeoning literature on efficient bargaining. Hall (1980) suggested that long-term firm-worker attachments that describe much of the workforce may provide the environment for achieving efficient labor choices while at the same time smoothing wage payments.

Here I propose a simple test for the importance of wage rigidities from long-term contracts, based on observing how employment behaves when firms and workers recontract. If contract rigidities are unimportant, then when a new bargain is signed this should have no impact on the path of employment. If, on the other hand, rigidities are important then we should observe employment adjusting after recontracting to undo movements in employment during the past contract that were excessive due to rigid wages. This exploits the point that wages are not rigid at the time of recontracting. This rebounding should show up as negative moving average terms for employment occuring af ter 
periods of recontracting.

Section 3 examines the behavior of employment for twelve manufacturing industries that are described by pattern bargaining. By using industries as the unit of observation I can observe quarterly data on employment. By using industries where most of the industry bargains within a time span of a month or two it is generally possible to associate bargaining points with particular quarterly observations for employment.

I find evidence that contract rigidities are important, causing considerably larger fluctuations in employment than would occur with flexible wages. The assumption that contracting is irrelevant for employment is rejected in several of the industries. The rejections are economically as well as statistically important. The most striking case is in motor vehicles where long-term contracts much more than double the size of fluctuations in employment. Overall the results suggest that contracting can explain as much as forty percent of the employment variability observed in the twelve industries.

I also examine the behavior of wage rates when new contracts are introduced. The results for employment suggest that wage rates should respond to past employment at the time of new contracts. Wage growth does respond to employment growth during the prior contract in several of the industries; but these wage responses are not very related to the pattern of employment responses across industries. Furthermore, this impact on wage rates is not robust to alternative specifications. This makes it difficult to interpret the employment evidence within the scenario of firms unilaterally choosing employment on the basis of the contract wage. In the final section I discuss alternative interpretations. 


\section{Setup}

I consider a simple bargaining problem between a representative firm and worker or, more realistically, group of workers.

\section{Labor demand and supply}

Let the firm's revenue in real terms from employing $L_{t}$ workers in period t be:

(1) Profits $t=a_{t} L_{t}-(b / 2) L_{t}^{2}$.

This yields the downward-sloping labor demand curve:

(2) $L_{t} d^{d}=\left(a_{t}-w_{t}\right) / b$

where $w$ is an explicit or implicit real wage rate. The stochastic parameter $a_{t}$ shifts the labor demand schedule.

Suppose the bargaining unt for workers views the opportunity cost of providing employment equal to $L_{t}$ as:

(3) Opportunity $\cos t_{t}=c_{t} L_{t}+(d / 2) L_{t}^{2}$.

I presume the, parameter $d$ to be nonegative, with labor's bargaining unit viewing the labor it provides as having a rising marginal opportunity cost. This yields the upward-sloping labor supply curve: 
(4)

$$
L_{t} s=\left(w_{t}-c_{t}\right) / d \quad .
$$

The stochastic parameter $c_{t}$ shifts the labor supply schedule (negatively).

\section{Flexible wage solution}

The choice for employment that equates supply and demand is:

$$
\mathrm{L}_{\mathrm{t}}^{*}=\frac{\mathbf{a}_{\mathrm{t}}}{\mathrm{b}+\mathrm{d}} \mathrm{t}_{-}
$$

I will refer to this as the flexible-wage solution for employment, al though, as discussed in the introduction, we might imagine settings without flexible wages that support this choice. This solution is clearly independent of the relation of time period to points of bargaining between the firm and workers. The proposition that the flexible-wage level of employment is independent of when bargaining occurs will hold much more generally than for the specific setup here. 1 The preposition that employment should not predictably rebound from realizations during the past contract holds even more generally. For example, the employment-contingent contracts discussed in Hall and Lillien (1979) are not completely indexed, yet preciude any predictable rebounding of employment at the time of recontracting.

\section{$\underline{\text { Rigid wage solution }}$}

As an alternative hypothesis to flexible-wage bargains, now suppose firms and workers bargain in advance to set a path for wage rates, then allow the firm to unilaterally choose employment over the life of the contract. In addition to being determined independently of the realizations for $a_{t}$ and $c_{t}$, 
I also restrict the path for wage rates (not compensation) to be independent of the level of employment.

This is clearly a very restrictive, very stramman-like model of rigid wages; but it is a useful straman model to consider. For one reason, it shares a similar structure to much analysed models of wage rigidities from Keynes (1936) through Fischer (1977) and Gray (1978). Secondly, I find in the next section that it is helpful in explaining employment behavior. The concluding section considers alternative models in light of the reported joint behavior of wages and employment.

I assume that the bargainers choose the predetermined wage rates so as to maximize the expected value of the f $1 \mathrm{rm} / \mathrm{uni}$ match. This presumes a fixed. side-payment component of compensation is available for providing necessary expected utility to each side of the bargain. Given $L$ equal to $L^{d}$ from equation (2), this optimal wage path is:

$$
w_{t}^{*}=\frac{\tilde{d a}}{t} \frac{\tilde{b}+\tilde{c}}{b+d}
$$

$\tilde{a}_{t}$ and $\tilde{c}_{t}$ are the expected values for $a_{t}$ and $c_{t}$ respectively at the $t$ ime the bargain covering period $t$ is decided. Employment for period $t$ is: 2

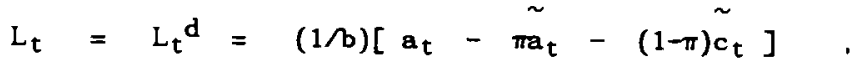

$$
\begin{aligned}
& \text { where } \pi=\mathrm{d} /(\mathrm{b}+\mathrm{d})
\end{aligned}
$$

Employment with rigid contracts will be affected by introducing a new contract. At new contract periods the estimates for demand and supply, $a_{t}$ and $c_{t}$. Will significantly improve because they will now reflect disturbances 
that occured during the life of the expired contract. This point is highlighted by rewriting equation (7) as:

$$
\begin{aligned}
& L_{t}=(1 / b)\left[a_{t}-\pi \tilde{a}_{t i o l d}-(1-\pi) \tilde{c} \tilde{c}_{t} i_{0 l d}\right. \\
& \left.-\pi\left(\tilde{a}_{t} i_{\text {new }}-\tilde{a_{t} i_{0 l d}}\right)-(1-\pi)\left(\tilde{c}_{t} i_{\text {new }}-\tilde{c}_{t} i_{o l d}\right)\right]
\end{aligned}
$$
$a_{t}$ iold and $c_{t}$ iold refer to the expected values of $a_{t}$ and $c_{t}$ given information available at the time the contract in effect period $t-1$ was determined. $\tilde{a}_{t} i_{n e w}$ and $\tilde{c}_{t} i_{n e w}$ refer to their expected values when the contract for period $t$ is made. If there is no new contract prior to period $t$ then no new information is used in setting the wage and the second line in equation (8) disappears. But if period $t$ does begin a new contract there will be adjustment in the wage and the second line of (8) will be nonzero.

Section 3 examines the importance of contracting by testing for the shifts in employment at the beginning of new contracts predicted by equation (8). Under rigid contracts with employment determined by labor demand employment overresponds to labor demand disturbances. If disturbances are primarily to labor demand, employment will change at the beginning of a contract to partially undo its movement during the prior contract. Under rigid contracts employment underresponds to labor supply disturbances. At the time of a new contract there should additionally be a change in employment in response to labor supply disturbances that occured during the prior contract. (If employment is determined by labor supply rather than demand, then the response at new contract points to past demand and supply disturbances would be simply reversed.) The next section discusses particular examples in more detail. 
If there is no persistence in labor demand and supply disturbances ( $a_{t}-c_{t}$ is white noise) then there will be no useful information to incorporate at the time of a new contract. Therefore the test I propose for examining contract rigidities would have no power. (It would also imply there is no efficiency loss in extending the length of contracts.) Empirically this is not a problem; disturbances to time-series equations for employment exhibit a great deal of persistence.

Of course, if for some reason the wage is not flexible even at contracting times--for instance, because of hysteresis as in Blanchard and Summers (1986)--this test would not detect it. Thus it might be necessary to look at the behavior of both employment and wages. (Wage behavior is examined in Section 3.)

\section{Examples}

Here I consider particular time-series forms for labor-demand and laborsupply disturbances and compare the time-series behavior of employment under flexible wages and rigid contracts.

Firstly, suppose the labor demand parameter $a_{t}$ follows the first-order autoregressive process:

$$
a_{t}=\delta a_{t-1}+\epsilon_{t} ;
$$

and that labor supply, reflected in $c_{t}$, is purely deterministic. (I will relax this momentarily.) The flexible-wage level for employment (ignoring deterministic components) then also follows a first-order process: 
For rigid-contract employment, on the other hand, it is necessary to distinguish bargaining points. If no new bargaining occurs between periods $t-1$ and $t$, then equation (8) reduces to:

$$
L_{t}=L_{t}{ }^{d}=\delta L_{t-1}+\epsilon_{t} / b
$$

By comparison, if period $t$ is the first period of a new contract employment is given by:

$$
\mathrm{L}_{\mathrm{t}}=\delta \mathrm{L}_{\mathrm{t}-1}+\epsilon_{\mathrm{t}} / \mathrm{b}-\pi \sum_{i=1}^{k(t)} \delta^{1}\left(\epsilon_{\mathrm{t}-1} / \mathrm{b}\right)
$$

$k(t)$ is the number of periods the previous contract was in effect. That is, bargaining occured between period $t-k-1$ and period $t-k$. The negative moving-average terms result from the wage rate at time $t$ adjusting to reflect the residual of disturbances that occured during the prior contract.

Therefore a simple test of rigid contract effects is to test for the presence of these negative moving average terms at the beginning of new contracts.

The size of the negative moving average terms indicates the importance of contract rigidities. With rigid contracts employment responds (b+d)/b times too much to a demand disturbance. This is simply equal to $1 /(1-\pi)$; where the parameter $\pi$ is identified from equation (11B). Identifying the parameter $\pi$ requires knowing the parameter $\delta$; but this can be estimated from the persistence in employment in periods without new contracts. The importance of long-term contracts also clearly depends on the length of 
contracts and whether they can be prematurely ended in the face of a large disturbance. These issues are addressed empirically in Section 3 .

For $a_{t}$ described by richer processes parallel tests for importance of contract rigidities can be similarly calculated.

When labor supply is stochastic it remains true that employment will exhibit extra negative moving average terms in periods of new contracts. This reversion is indicative of how much employment overreacts to demand disturbances because of the rigid contracts. It does not indicate, however, the effect of rigid contracts causing employment to underrespond to supply disturbances.

Again suppose that $a_{t}$ is described by the AR(1) process in equation (9), but now suppose the labor supply parameter $c_{t}$ is stochastic and given by:

$$
\begin{aligned}
& \mathrm{c}_{\mathrm{t}}=\mathrm{qa_{ \textrm {t } }}+\mathrm{v}_{\mathrm{t}} \\
& \text { where: } \mathrm{v}_{\mathrm{t}}=\beta \mathrm{v}_{\mathrm{t}-1}+\mu_{\mathrm{t}}
\end{aligned}
$$

A nonzero parameter $q$ allows demand and supply to be correlated. For example, an increase in labor demand might be correlated with increased demand at other firms, which raises the opportunity cost of labor. This would correspond to $q$ greater than zero. There is an additional supply disturbance, $v$, which $I$ assume is uncorrelated with demand and has an autocorrelation parameter of $\beta$. For simplicity I treat here the case where supply and demand disturbances exhibit equal persistence ( $\beta$ equal to $\delta$ ). This conveys the intuition of the more general case. The more general case is presented in a footnote. ${ }^{3}$

With $\beta$ equal to $\delta$, employment under flexible wages would also follow an 
$A R(1)$ with parameter $\delta$.

(13)

$$
\mathrm{L}_{\mathrm{t}}^{*}=\delta \mathrm{L}_{\mathrm{t}-1}^{*}+\frac{(1-\mathrm{q}) \epsilon_{\mathrm{t}}-\mu_{\mathrm{t}}}{\mathrm{b}+\mathrm{d}}
$$

Turning to rigld contracts. Wi th no new bargain between periods $t-1$ and t employment is given by:

$$
L_{t}=\delta L_{t-1}+\epsilon_{t} / b
$$

It has the same autocorrelation as $L^{*}$. but responds more dramatically to demand disturbances and not at all to supply disturbances. The response to $\epsilon_{t}$ is $\frac{b+d}{b(1-q)}$ times as large as with flexible wages; this equals $\frac{1}{(1-q)(1-\pi)}$ If $q$ is positive the labor supply curve is effectively steeper because when labor demand is high labor supply is low. This amplifies the cost of rigid wages.

In the first period of a new contract employment makes up for past overreactions to $\epsilon$ and underreactions to $\mu$. Employment in these periods is described by:

$$
\mathrm{L}_{\mathrm{t}}=\delta \mathrm{L}_{\mathrm{t}-1}+\epsilon_{\mathrm{t}} / \mathrm{b}-\sum_{\mathrm{i}=1}^{\mathrm{k}(\mathrm{t})} \delta^{i}\left(\epsilon_{\mathrm{t}-\mathrm{i}} / \mathrm{b}\right)-(1-\pi) \sum_{\mathrm{i}=1}^{k(\mathrm{t})} \delta^{\mathrm{i}}\left(\mu_{\mathrm{t}-\mathrm{i}} / \mathrm{b}\right)
$$

where $\Phi=\pi+q-\pi q$.

Estimating the negative moving average terms yields an estimate of $\Phi$, which correctly measures how much rigid contracts cause employment to overrespond to demand. Yaking up for past disturbances to $v$ will show up as extra 
variance in time periods of new contracts. One could theoretically measure the importance of this effect by measuring heteroscedasticity in employment equations caused by time periods with new contracts. This is discussed in the following empirical section.

\section{Results}

I test for the importance of wage rigidities in twelve manufacturing industries that are not only heavily unionized but that also either bargain as an industry or else usually follow a general industry bargaining pattern. The twelve industries are listed in Table 1. The industries are very uneven in size: together they have made up about fifteen percent of employment in manufacturing since World War II.

Even for these twelve selected industries the matching of employment data to contracting points is of ten much less than perfect. In several of the industries noticably less than 100 percent of the industry, as measured by the employment figures, are covered in the pattern bargains. This is particularly true for Samills, Glass Containers, Metal Cans, Cigarettes, and Petroleum. Another problem is that the pattern settlements do not always fit nicely into a period of a couple months, so that a time period can be accurately depicted as the first periad of a new contract. This bias is particularly important for Farm Machinery, Meat Packing, and Petroleum where strikes of ten dragged out the pattern of settlements. Each of these problems 
bias estimation toward finding no effect of contracting on employment.

Proceeding, consider the example discussed directly above with $a_{t}$ described by an $A R(1)$ process, but with no independent labor supply disturbances ( $v_{t}$ nonzero, but $\mu_{t}$ identically equal to zero). This gives the following equation for employment:

(15) $\mathrm{L}_{\mathrm{t}}=\delta \mathrm{L}_{\mathrm{t}-1}+\left(\epsilon_{\mathrm{t}} / \mathrm{b}\right)-\Phi \mathrm{Z}_{\mathrm{t}}\left\{\sum_{\mathrm{i}=1}^{\mathrm{k}(\mathrm{t})} \delta^{i}\left(\epsilon_{\mathrm{t}-\mathrm{i}} / \mathrm{b}\right)\right\}$.

$Z_{t}$ is a dummy variable which equals one for first period of a new contract and zero otherwise.

\section{Examining Growth Rates}

As a first step in examining the data, I simply test whether the rate of growth in employment at the beginning of new contracts responds significantly to the rate of growth in employment that occured during the prior contract. I examine this case because it is a parsimonious manner to present the data to the reader. This coincides exactly with equation (15) for the particular case of $a_{t}$ equal to a random walk ( $\delta$ equal to one). Immediately below I estimate $\delta$ as a prelude to testing for contracting effects; the estimate for $\delta$ in most of twelve industries is considerably less than one.

The equation estimated is:

$$
\text { (16) } \begin{aligned}
\mathrm{L}_{\mathrm{t}}-\mathrm{L}_{\mathrm{t}-1}=\left(\epsilon_{\mathrm{t}} / \mathrm{b}\right)+\Gamma \mathrm{Z}_{\mathrm{t}} & -\Phi \mathrm{Z}_{\mathrm{t}}^{\mathrm{k}(\mathrm{t})-1} \sum_{\mathrm{i}=1}\left(\mathrm{~L}_{\mathrm{t}-\mathrm{i}}-\mathrm{L}_{\mathrm{t}-1-\mathrm{i}}\right) \\
& -\theta \sum_{\mathrm{i}=1}^{9}\left(\mathrm{~L}_{\mathrm{t}-\mathrm{i}}-\mathrm{L}_{\mathrm{t}-1-\mathrm{i}}\right)
\end{aligned}
$$


There are three alterations going from equation (15) to (16). I have added the dummy variable $Z_{t}$ into the equation directly; this allows a predictable effect of recontracting on the average growth of employment, as opposed to the rebounding effect I have focused on. Secondly, the summation over the prior contract examines the last $k-1$ periods of the $k$ period contract. The first period of the prior contract would reflect the rebound effect for which I am testing. Therefore 1 ts inclusion would require 1 terative estimation. Ignoring the innovation in the first period of the prior contract does not bias the estimates because by definition the innovations over the contract are not correlated. Because the contracts in my sample average about 10 periods (quarters), there is also relatively little loss in information. Finally, the equation allows the growth in employment to be related to employment growth over the nine previous periods. I include this term to allow for the possibility that employment growth responds to past employment growth in all periods, not just the first period of contracts. This provides a more meaningful estimate for the parameter $\Phi$. I choose a lag length of 9 periods (quarters) because in my sample $k-1$ averages 9 periods.

For employment I use the natural $\log$ of production worker employment for the months of January, April, July, and October for the years 1958 to 1986 (for Aluminum data were only avallable for 1964 to 1986). This data is from the BLS establishment surveys. The bargaining periods were determined from reports in the Current Wage Developments either directly or from the data set derived from the Current Wage Developments by Wayne Vroman and expanded by Beverly Hirtle. The industries average about 11 bargains each over the sample period. I call a period the first perlod of a contract if agreement on a new contract was reached during one of the preceding three months. 
Estimation is in two steps. In the first step I estimate a time trend and four seasonal dumies by industry using only those time periods that are not quarters with new contracts. This is about ninety percent of the observations. Given these consistent estimates, I then remove trend and seasonals for all time periods and estimate equation (16).

For several of the industries there were a number of strikes during the sample period. The relevant periods were determined from the Current Wage Developments. 4 In estimating the trend and seasonals I remove alI observations during which strikes occured or which follow a strike period. In estimating equation (16) I remove periods with strikes and for periods following strikes I examine employmment growth since the previous nonstrike observation. Similarly, the distributed lags of innovations contained in equation (16) do not reflect periods contaminated by strikes.

I first present results for equation (16) pooling the 12 industries. (Trend and seasonals, however, are estimated by industry.) The results are:

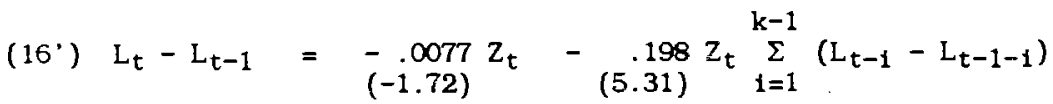

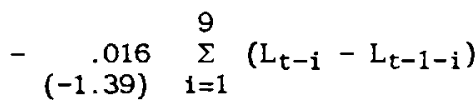

$$
\begin{aligned}
& \left\{\begin{array}{lll}
\mathrm{R}^{2}=.027 & \mathrm{SEE}=.047 & \text { D.W. }=2.14
\end{array}\right\}
\end{aligned}
$$

The impact of contracts on employment is very significant. The estimate for $\Phi$ shows that twenty percent of the innovation in employment during the prior contract is typically undone in the first quarter after recontracting. This impact is statistically as well as economically important. By contrast, 
the estimate for $\theta$ implies there $1 \mathrm{~s}$ only a small amount of regress in growth of employment except at the beginning of new contracts.

Beyond the rebound effect, the beginning of contracts is associated with typically a slight reduction (.77 of one percent) in the level of employment. I show below that this effect varies greatly across industries. Models of rigid wages where employment is determined by the minimum of labor supply and labor demand (e.g., Hall and Lazear. 1984) would predict increases in employment with recontracting. The significant estimate for $\Phi$ together with the slightly negative estimate for $\Gamma$ constitutes evidence against these models.

Table 2 presents estimates for equation (16) separately for each of the twelve industries. Because there are only about 11 new contracts per industry during the sample period, the standard errors estimating by industry are generally unavoidably large.

The most striking contracting effects are for motor vehicles. With new contracts, employment in motor vehicles undoes almost half of its movement during the preceding contract. There is also a large increase in employment of twelve percent on average associated with new contracts. Because motor vehicles also exhibits the most volatile employment of the twelve industries. it also importantly influences the pooled estimates. In five other industries. however, the estimate for $\Phi$ is near or even greater than the pooled estimate. These are sawmills, aluminum, metal cans, cigarettes, and men's apparel;

The remaining six industries show no rebound effect of new contracts on employment. (The steel and tire industries do show predictable decreases in employment at the beginning of contracts.) In three of these industries, 
meatpacking, farm machinery, and petroleum, testing for contracting effects may be clouded by many strike occurances which upset the bargaining pattern.

According to the rigid wage model presented above. the adjustments in employment at the beginning of contracts reflects adjustments occuring in wage rates. The wage equation that corresponds to equation (15) is:

(17) $w_{t}=\delta w_{t-1}+b \Phi z_{t}\left\{\sum_{i=1}^{k(t)} \delta^{i}\left(\epsilon_{t-i} / b\right)\right\}$.

I begin by simply examining the behavior of wage growth at the beginning of new contracts. The wage equation that corresponds to estimated employment equation (16) is:

(18) $W_{t}-W_{t-1}=\alpha Z_{t}+b \Phi Z_{t} \sum_{i=1}^{k(t)-1}\left(L_{t-1}-L_{t-1-1}\right)$

$$
+\Omega \sum_{i=1}^{9}\left(L_{t-i}-L_{t-1-i}\right) .
$$

I measure wages with BLS data on average hourly earnings of production workers, as with employment, for the months of January, April, July, and October for the years 1958 through 1986 (1964 through 1986 for Aluminum). Straight-time wages are not avallable for before 1972 for the 4-digit industries. I deflated the nominal wage rates by the Consumer Price Index for Urban Workers. The estimated wage-growth equation includes a trend and seasonal dumies. As with the employment equation, these terms were estimated in a first step using only time periods without new contracts.

I first present results pooling the 12 industries. (Trend and seasonals differ by industry.) The results are: 


$$
\begin{aligned}
& \text { (18') } w_{t}-w_{t-1}=\underset{(8.51)}{.0146} z_{t}+\underset{(3.53)}{.048} z_{t} \underset{i=1}{k-1}\left(L_{t-1}-L_{t-1-1}\right) \\
& -\underset{(-2.82)}{.012} \sum_{i=1}^{9}\left(L_{t-1}-L_{t-1-1}\right) \\
& \left\{\mathrm{R}^{2}=.062 \quad \mathrm{SEE}=.019 \quad \text { D.W. }=2.26\right\}
\end{aligned}
$$

There is an effect of employment growth during the past contract on wage growth at the beginning of contracts. The estimate states that if employment grew by 10 percent faster than normal over the prior contract then wages grow an additional half percent with the new contract. Quantitatively this effect appears small. To generate the employment effect estimated above would require an elasticity response in employment to wages of four. Furthermore. I demonstrate momentarily that the pattern of wage responses across industries does not correspond to the pattern in employment responses. In periods without new contracts there is a slight negative response of wage rates to employment growth during the prior 9 quarters.

The most striking result is a predictable increase in wages of 1.5 percent at the beginning of a new contract. It is well known that union contracts are of ten front loaded; in fact the BLS publishes data on wage changes in major bargaining agreements separately for the first year of contracts.

Results for equation (18) by industry are given in Table 3 . There are strong reactions in wages at the beginning of contracts to employment growth during the prior contract in glass containers, steel, metal cans, petroleum. and to a lesser extent in aluminum and meat packing. The industries which 
exhibit reactions in wages do not correspond to those that show responses in employment. Of these six industries, only three, glass containers, metal cans, and aluminum. demonstrate rebounds in employment at new contract times. The response in wages, without response in employment, in steel, petroleum, and meat packing could be interpreted as evidence of contract wage rigidities that do not have allocative importance for employment. What is difficult to interpret are the industries, particularly motor vehicles, that display marked rebounding of employment with new contracts, but show no reaction in hourly wages in Table 3 .

The industry pattern of wage increases at the beginning of contracts is also hard to reconcile with the behavior in employment within a model where firms unilaterally determine employment. The two industries which show the most front loading are glass containers and motor vehicles: but these industries on average show higher than usual employment growth at the beginning of contracts.

\section{Parameter Estimates of Rebounding}

I now want to estimate the time-series process for employment together with the impact of recontracting. I continue to consider the employment equation (15): but estimate the first-order coefficient $\delta$ for $a_{t}$. The estimated equation is:

$$
-\theta \underset{i=1}{9} \delta^{1}\left(\epsilon_{t-i} / b\right)
$$


Estimation again takes place in two steps. In the first step, which excludes time periods with new contracts. I now estimate the first-order coefficient $\delta$ as well as trends (both linear and quadratic) and seasonal dumies. The estimates for $\delta$ by industry are given in the first column of Table 4. The estimates average .874 across industries, ranging from a low of .777 in cigarettes to a high of .935 in farm machinery.

Given the estimate for $\delta$ and residuals as estimates for the Innovations to employment. $\in /$, it then straightforward to construct the distributed lag of disturbances during the prior contract that appears as a regressor in equation (19). The second step is then to estimate the equation given this generated regressor. (To obtain consistent estimates of the standard errors for equation (19) requires a correction because $\delta$ and the innovations are estimated rather than known. The t-statistics presented below do not reflect this correction; however, they do represent consistent t-tests against the null hypothesis of no contract effect on employment.)

I first present results pooling the 12 industries. (But trends. seasonals, and $\delta$ estimates are industry specific.)

$$
\begin{aligned}
& \text { (19.) } \mathrm{L}_{t}-\hat{\delta} \mathrm{L}_{\mathrm{t}-1}=-\underset{(-1.97)}{-.0085} \mathrm{Z}_{\mathrm{t}}-\underset{(6.56)}{.344} \mathrm{Z}_{\mathrm{t}} \sum_{\mathrm{i}=1}^{\mathrm{k}-1} \hat{\delta^{1}}\left(\epsilon_{\mathrm{t}-1} / \mathrm{b}\right) \\
& +\underset{(1.31)}{.021} \sum_{i=1}^{9} \hat{\delta^{i}}\left(\epsilon_{t-i} / b\right) \\
& \left\{\mathrm{R}^{2}=.035 \quad \mathrm{SEE}=.045 \quad \text { D.W. }=2.08\right\}
\end{aligned}
$$

The major change is that the size of the rebound effect, $\Phi$, increases to .34 . Thus the data suggests that employment rebounds to undo fully one third of 
the residual of disturbances that occured during the prior contract. This effect is economically large. Calculations below translate this estimate into a result that rigid contracts can explain much of the variability in employment in these twelve industries.

Replacing the value for $\delta$ of one with an estimated value of less than one increases the estimate of $\Phi$ because the regressor, the accumulated innovations in employment during the prior contract, becomes smaller. Consider an innovation in employment that occurs during the early periods of a contract. If, for instance, $\delta$ equals .9 and the disturbance occured 10 quarters before the end of the contract, then when the contract expires only 35 percent (equals $.9^{10}$ ) of the original disturbance remains to which new contracts need respond.

Table 4 presents estimates for equation (19) separately by industry. The relative pettern across the twelve industries appears much as before. Motor vehicles remains by far the most striking case. For motor vehicles I estimate that with recontracting employment undoes three fourths of the remainder of disturbances from the prior contract.

The size of the negative moving average terms at the beginning of contracts suggests to what extent employment overresponds to demand during a contract. Alone, however, they do not give the importance of contract rigidities in explaining the variability of employment. For a given value of $\Phi$, contracts $\mathbf{1 1 1}$ be less important if contracts are short in duration or if the parties choose to end contracts prior to their scheduled ending in response to large disturbances. From estimating equation (19), however, I obtain estimates of the disturbances to the employment equation, an estimate of $\delta$, and an estimate of $\Phi$. From these $I$ can construct an estimate of the 
hypothetical path that employment would follow under perfectly flexible wages. By comparing this constructed employment series to the actual it is possible to gauge the importance of contracts.

If $a_{t}$ follows an $A R(1)$ and pure supply disturbances are relatively unimportant, then the estimated path employment would follow under perfectly flexible wages is given by:

$$
\hat{L}_{t}^{*}=\hat{\delta} \hat{L}_{t-1}^{*}+(1-\hat{\Phi})\left(\hat{\epsilon_{t}} / \mathrm{b}\right)
$$

Table 5 gives the sample standard deviation of flexible-wage employment in equation (20) compared to the standard deviation for actual employment as described by equation (19).

The results suggest that as much as forty percent of employment variability in the 12 industries can be attributed to contract rigidities. This is primarily because for motor vehicles, a very large and very variable industry, the estimates suggest three quarters of varlability is created by contracts. In four other industries, sawmills, glass containers, aluminum, and cigarettes, a considerable fraction of variability is attributed to rigic contracts. Across the twelve industries the average estimate of variability is 16 percent lower under flexible wages than under actual contracts. Weighting industries by their sizes, however, the estimates suggest 40 percent of employment variability in the twelve industries come from rigid contracts.

If pure supply disturbances are important the variabilities given in Table 5 will misrepresent the impact of rigid contracts on employment variability. As discussed above, if employment is demand determined in the 
short run, rigid contracts can reduce employment variability by keeping employment from responding to supply disturbances. The estimates in Table 4 will remain suggestive of how much contracts cause employment to overrespond to demand disturbances.

The prior section suggested the importance of supply disturbances might be inferred from the size of absolute errors in periods of new contracts. Correction for supply disturbances during the past contract should create extra variability at the beginning of a contract. There is some evidence of greater variability. Average squared errors are larger for the first period of new contracts in ten of the twelve industries. In the five industries steel, metal cans, motor vehicles, petroleum, and tires the squared errors are much larger--two or three times larger--in the first period of contracts. It is difficult, however, to infer the importance of supply disturbances from this heterscedasticity. For one thing, the equation estimated for first perlods of contracts differs from other periods; thus the squared errors are not strictly comparable. Secondly, the correction made for strikes is likely to create larger squared errors at the beginning of contracts. Thirdly, it is necessary to have an estimate of the persistence of supply disturbances: this is difficult under an assumption that employment is demand determined in the short run.

Lastly. I estimate the behavior of wages dictated by equation (17). The estimated equation takes the form:

$$
\begin{aligned}
W_{t}-\delta W_{t-1}=\alpha Z_{t}+ & \quad b \Phi z_{t} \sum_{i=1}^{k(t)-1} \delta^{i}\left(\epsilon_{t-1} / b\right) \\
& +\Omega \sum_{i=1}^{9} \delta^{1}\left(\epsilon_{t-i} / b\right)
\end{aligned}
$$


This generalizes the examination above of growth rates in wages:

For the constructed right-hand regressors I use the estimates of $\delta$ by industry and residuals from the estimated employment equation (19). As before, in a first step I excluded periods with new contracts and estimated the autocorrelation parameter in wages as well as trends (linear and quadratic) and seasonal dumies. The rage-equation estimates for $\delta$ by industry appear in the first column of Table 6 . The average estimate across industries is .893 . This is a bit higher than the average estimate in the employment equations of .874 . Furthermore, comparing the first colums of Tables 4 and 6 , one sees little relation between the industry pattern of autocorrelations in the employment and wage equations.

The second step is to estimate equation (21). I first present results pooling the 12 industries.

$$
\begin{aligned}
& \left(21^{\circ}\right) W_{t}-\hat{\delta} W_{t-1}=\underset{(7.81)}{.0130} z_{t}+\underset{(.11)}{.0022} z_{t} \sum_{i=1}^{k-1} \hat{\delta^{1}}\left(E_{t-1} / b\right)
\end{aligned}
$$

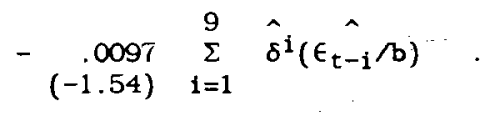

$$
\begin{aligned}
& \left\{\mathrm{R}^{2}=.045 \quad \mathrm{SEE}=.018 \quad \text { D.W. }=2.19\right\}
\end{aligned}
$$

With this specification. wages continue to display front laading, but now show no response to employment behavior during the preceding contract. This change in results from the wage-growth case is surprising, particularly because the data here are quasi differenced given the average estimate for $\delta$ of .849 . 
Table 6 presents results by industries. Some of the positive impact of past employment on wages at the beginning of new contracts persists in glass containers, steel, aluminum, metal cans, and petroleum; but it is much weaker than in the wage growth equations.

One possible explanations is that labor unions grant concessions in the form of foregoing future pay increases rather than current cuts in pay. Verbal descriptions of bargaining in several of the industries supports this contention. I additionally examined whether employment behavior during the prior contract significantly determines wage growth over the entire present contract. I found little evidence of such behavior.

\section{Conclusions}

I find evidence that recontracting matters for the behavior of employment. At the beginning of new contracts employment shifts to undo part of the residual of disturbances that occured during the prior contract. This effect shows up in nearly half of the twelve industries I examine; but by far the most dramatic contracting effects are for motor vehicles.

I interpret this as evidence against efficient contracting. It is also counter to hysteresis models (e.g.. Blanchard and Summers) that explain persistence in disturbances beyond the length of contracts from union membership effects.

This employment behavior is consistent with rigid-wage bargaining models 
that assume the path of wages is determined at contracting and then firms determine the level of employment over the life of the agreement. The evidence presented for average hourly carnings, however, is not at all consistent with this view. In a number of industries wage growth at the beginning of contracts does respond to employment growth over the prior contract. But these typically are not the same industries that display employment rebounding with recontracting. Furthermore, the response in wages is much smaller when estimated in levels.

One explanation for the contrary behavior of employment and wages is that industry measures for average hourly earnings may be very poor measures of the marginal cost of labor. Consider the auto industry. Above I found that new contracts have a very dramatic impact on employment in motor vehicles; but there was no response of hourly earnings to past disturbances at the beginning of a contract. A recent episode that called for a large adjustment in wages were agreements reached in Spring $1982 .{ }^{5}$ Employment had fallen by about 35 percent since the existing contracts began in 1979; yet the real wage upon entering the new contract period stayed the same or slightly increased. Examining the bargaining agreements directly (BLS Current Wage Developments. March 1982 and April 1982). however, reveals a great deal of action on compensation that average hourly earnings fail to capture. One striking feature is that the new contracts allowed the auto companies to hire new workers at 85 percent of the standard wage rate (previously they could be hired at 95 percent). Nine paid personal holiday days per year were eliminated. Furthermore, there was a significant increase in the guaranteed earnings the automakers agreed to pay laid-of $f$ workers. Each of these provisions has an important effect on the price of employment 
but is not captured by hourly earnings.

Another possibility is that employment is not determined unilaterally by firms on the basis of the contemporaneous price of labor, but renegotiation nevertheless allows the bargainers to arrive at more efficient choices for labor. Returning to the 1982 auto agreements as an example, in exchange for the above union concessions plus significant reductions in scheduled wage increases (as opposed to reductions in the level of wages), the companies agreed to a number of employment provisions. These included a two-year moratorium on plant closings and limits to future rates of layoffs. Rather than viewing employment as unilaterally determined by firms. it may be more realistic to view many contracts as specifying a path for wages and a path with upper and lower bounds for employment, where the distance between the upper and lower bounds increases with the amount of time into the contract. One can imagine models of imperfect-information optimizing contracting that imply giving the firm increased latitude to choose employment as the contract proceeds. What is less obvious is what reasonable restrictions on contracting would lead to the systematic overreactions to disturbances I find in employment behavior. 


\section{NOTES}

1. The proposition would fail if labor supply or demand are importantly influenced by weal th effects generated purely from the bargaining process. Even then, however. I belive it would be very difficult to explain the systematic adjustments in employment I find in Section 3.

2. Along this wage and employment path employment will at times exceed labor supply at the marginal wage $w$. Given the fixed payment. F, however. the average wage can be sufficiently high that quits by workers are not a problem.

3. If $\beta$ does not equal $\delta$ then employment cannot be described by an $\operatorname{AR}(1)$. Employment and wages together, however, can be described by first-order vector autoregressions. Under flexible wages these are:

(A1) $\quad L_{t}^{*}=\left[\beta+\frac{b(1-q)(\delta-\beta)}{b+d} L_{t}^{*}{ }^{*}+\frac{(1-q)(\delta-\beta)}{b+d} *_{t-1}^{*}+\frac{(1-q) \epsilon_{t}-\mu_{t}}{b+d}\right.$

$$
W_{t}^{*}=\left[\delta-\frac{b(1-a)(\delta-\beta)}{b+d} W_{t-1}^{*}+\frac{b(d+a b)(\delta-\beta)}{b+d} L_{t}^{*}+1+\frac{(d+q b) \epsilon_{t}+b \mu t}{b+d}\right.
$$

Substituting for the wage yields the following AR(2) for employment with an error that is the sum of two first-order moving averages.

$$
\begin{aligned}
L_{t}^{*}=[\delta+\beta & -\frac{b(1-q)(d+q b)(\delta-\beta)^{2}}{b+d} L_{t}{ }_{t}^{*}-\left[\delta \beta+\frac{b(1-a)(d+b a)(\delta-\beta)^{2}}{b+d} L_{t}\right. \\
& +(1-q)\left[\underline{\epsilon}_{t} \frac{-\beta \epsilon_{t}}{b+d}\right]-\left[\underline{\mu}_{t} \frac{-\delta \mu}{b+d} t-1\right] .
\end{aligned}
$$

Turning to the rigid wage solution, it is convenient to construct the argument $\left(L_{t}-\delta L_{t-1}\right)$. Using equation (7), this equals : 
(A4) $L_{t}-\delta L_{t-1}=\epsilon_{t} / b-\Phi\left(\tilde{a}_{t}-\delta \tilde{a}_{t-1}\right) / b-(1-\pi)\left(\tilde{\mu}_{t}-\tilde{\mu}_{t-1}\right) / b$

$$
+(1-\pi)(\delta-\beta) \tilde{\mu_{t-1}}
$$

If period $t$ is not the first period of a contraact this reduces to:

(A5) $L_{t}-\delta L_{t-1}=\epsilon_{t} / b+(1-\pi)(\delta-\beta) \mu_{t-1}$.

If period $t$ is neither the first or second period of a contract. equation (A5) can be compared with its expression lagged once to yleld a second-order employment eqution with a first-order moving average error.

(A6) $\mathrm{L}_{\mathrm{t}}=\delta \mathrm{L}_{\mathrm{t}-1}+\beta\left(\mathrm{L}_{\mathrm{t}-1}-\delta \mathrm{L}_{\mathrm{t}-2}\right)+\left(\epsilon_{\mathrm{t}}-\beta \epsilon_{\mathrm{t}-1}\right) / \mathrm{b}$

$$
=(\delta+\beta) L_{t-1}-\delta \beta L_{t-2}
$$

Equations for employment for the first and second periods of contracts can be derived in a similar fashion. These are respectively:

$$
\begin{aligned}
& L_{t}=(\delta+\beta) L_{t-1}-\delta \beta L_{t-2}+\left(\epsilon_{t}-\beta \epsilon_{t-1}\right) / b \\
&-\Phi \sum_{i=1}^{k} \delta^{i}\left(\epsilon_{t-i} / b\right)-(1-\pi) \sum_{i=1}^{k} \beta^{i}\left(\mu_{t-1} / b\right)
\end{aligned}
$$

(A8) $\mathrm{L}_{\mathrm{t}}=(\delta+\beta) \mathrm{L}_{\mathrm{t}-1}-\delta \beta \mathrm{L}_{\mathrm{t}-2}+\left(\epsilon_{\mathrm{t}}-\beta \epsilon_{\mathrm{t}-1}\right) / \mathrm{b}$

$$
+\beta \Phi \sum_{i=1}^{k} \delta^{i}\left(\epsilon_{t-1-i} /\right)+\delta(1-\pi) \sum_{i=1}^{k} \beta^{i}\left(\mu_{t-1-i} /\right)
$$

As in the text case, the beginning of a contract is associated both with rebounding from demand disturbances that occured during the past contract as well as adjusting to reflect pure supply disturbances that occured. 
4. For the twelve industries I corrected for 31 strike occurances covering 42 quarters. The three industries Farm Machinery, Meat Packing, and Petroleum Refining contributed more than 60 percent of the strike activity. In most cases the strike dumies occur in the period prior to the first period of a new contract. In only a couple cases did a strike dummy coincide with the first period of a new contract so that the estimated effect of the new contract was lost.

5. The bargaining in Spring of 1982 occured prior to the expiration date of contracts signed in 1979. The first contract was signed with Ford in February. Agreements followed at General Motors and American Motors in April. Chrysler had been out of bargaining sync with Ford and General Motors since 1980. American Motors was generally out of sync. but was in line on this occasion. 


\section{REFERENCES}

Barro; R. J., "Long-Term Contracting, Sticky Prices, and Monetary Policy." Journal of Monetary Economics 3 (July 1977): 305-16.

Blanchard, O., and Summers, L., "Hysteresis and the European Unemployment Problem." NBER Macroeconomics Annual 1 (1986): 15-78.

Fischer, S., "Long-Term Contracts, Rational Expeccctations, and the Optimal Money Supply Rule." Journal of Political Economy 85 (February 1977): 191-205.

Geary. P. T., and Kennan. J., "The Employment-Real Wage Relationship: An International Study." Journal of Political Economy 90 (August 1982): 854-71.

Gray. J. A., "On Indexation and Contract Length." Journal of Political Economy 86 (February 1978): 1-18.

Hall, R. E., "Employment Flutuations and Wage Rigidity." Brookings Papers on Economic Activity (1980): 91-123.

Hall, R. E., and Lilien, David, "Efficient Wage Bargains Under Uncertain Supply and Demand." American Economic Review 69 (December 1979): 868-79.

Hall, R. E., and Lazear, E., "Excessive Layoffs and Quits in Response to Demand." Journal of Labor Economics (1984).

Lindbeck, A., and Snower, D. J., "Transmission Mechanisms from the Product to the Labor Market." Manuscript, University of London, August 1987. 
Prescott, E. C.. "Theory Ahead of Business Cycle Measurement." Federal Reserve Bank of Minneapolis, Research Department Staff Report 102. February 1986.

Rotemberg. J., "The New Keynesian Microf oundations." NBER Macroeconomics Annual 2 (1987): 69-104.

Summers, L., "Should Keynesian Economics Dispense Wi th the Phlllips Curve?" In Unemployment, Hysteresis and the Natural Rate Hypothesis, edi ted by R. Cross. London: Basil Blackwell, 1987. 


\section{Table 1 -- List of Industries}

\begin{tabular}{|c|c|c|}
\hline Industry & SIC \# & $\begin{array}{l}\text { Production worker } \\
\text { Employment } \\
\text { in } 1974\left(1,000^{\prime} \text { s) }\right.\end{array}$ \\
\hline $\begin{array}{l}\text { Sawmills and } \\
\text { Planing Mills }\end{array}$ & 2421 & 168.3 \\
\hline Glass Containers & 3211 & 66.0 \\
\hline $\begin{array}{l}\text { Blast Furnaces } \\
\text { and Basic Steel }\end{array}$ & 331 & 456.4 \\
\hline Primary Aluminum & 3334 & 28.9 \\
\hline Metal Cans & 3411 & 60.3 \\
\hline Farm Machinery & 352 & 93.5 \\
\hline $\begin{array}{l}\text { Motor Vehicles } \\
\text { and Equipment }\end{array}$ & 371 & 668.6 \\
\hline Meat Packing Plants & 2011 & 140.3 \\
\hline Cigarettes & 211 & 34.7 \\
\hline $\begin{array}{l}\text { Men's and Boys' } \\
\text { Suits and Coats }\end{array}$ & 231 & 98.0 \\
\hline Petroleum Refining & 291 & 90.0 \\
\hline $\begin{array}{c}\text { Tires and Inner } \\
\text { Tubes }\end{array}$ & 301 & 87.7 \\
\hline Sum of Twelve & & 1,993 \\
\hline Total Manufacturing & & 13.957 \\
\hline
\end{tabular}


TABLE 2 -- Results by Industry for Employment Equation (16)

Sawmills
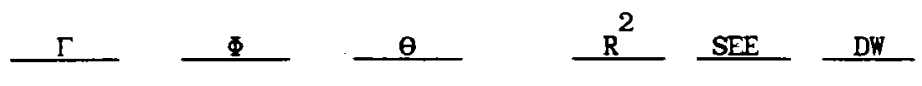

$$
.0074
$$

$(2.08)$

$(.014$

.056

.029

1.38

Glass

Containers

.0146

(1. 39)

.092
$(.56)$

.042
$(.88)$

$.027 \quad .032$

2.27

Steel

$-.0665$

$-.181$

$(-4.12)$

$(-1.34)$

.062

(1.61)

Aluminum

$-.0510$

$(-2.25)$

.199

(1. 46)

.039

(.88)

Metal Cans

-.0243
$(-2.37)$

.201
$(1.87)$

$-.017$

$(-.43)$

Farm

Machinery

$$
\begin{array}{ll}
-.0135 & -.066 \\
(-.58) & (-.51)
\end{array}
$$

Motor

Vehicles

.1212

(4.39)

.494

$(4.56)$

$-.008$

$(-.22)$

Meat

Packing

$-.0127$

$-.382$

$(-1.95)$

.148

(3.06)

Cigarettes

-.0020
$(-.12)$

.187

(1.36)

.051
$(1.06)$

\section{Men's}

Apparel

$-.0403$

$(-3.13)$

.176

(1.61)

.018

(.51)

Petroleum

$$
\begin{aligned}
& -.0097 \\
& (-.67)
\end{aligned}
$$

$-.047$

$(-.28)$

.083

(1.35)

Tires

-.0266
$(-2.13)$

$-.013$

$(-.11)$

.044

(1.04)

$.074 \quad .031$

$.165 \quad .049 \quad 1.42$

$.089 \quad .061 \quad 1.77$

$.006 \quad .059 \quad 2.06$

$.269 \quad .082 \quad 1.95$

$.112 \quad .020 \quad 2.01$

$.059 \quad .036 \quad 2.48$

$\begin{array}{lll}.118 & .039 & 2.11\end{array}$

$.021 \quad .050 \quad 2.57$

$.053 \quad .041 \quad 2.06$ 
TABLE 3 -- Results by Industry for Wage Equation (18)

\begin{tabular}{|c|c|c|c|c|c|c|}
\hline & $\alpha$ & $\mathrm{b \Phi}$ & $\Omega$ & $\mathrm{R}^{2}$ & SEE & DW \\
\hline Sawmills & $\begin{array}{l}-.0003 \\
(-.05)\end{array}$ & $\begin{array}{l}.016 \\
(.21)\end{array}$ & $\begin{array}{r}-.042 \\
(-1.97)\end{array}$ & .035 & .019 & 2.30 \\
\hline $\begin{array}{l}\text { Glass } \\
\text { Containers }\end{array}$ & $\begin{array}{l}.0248 \\
(6.41)\end{array}$ & $\begin{array}{r}.336 \\
(5.57)\end{array}$ & $\begin{array}{l}-.010 \\
(-.60)\end{array}$ & .394 & .012 & 2.38 \\
\hline Steel & $\begin{array}{l}.0020 \\
(.34)\end{array}$ & $\begin{array}{r}.217 \\
(4.14)\end{array}$ & $\begin{array}{r}-.027 \\
(-1.80)\end{array}$ & .137 & .019 & 2.18 \\
\hline Aluminum & $\begin{array}{l}.0152 \\
(1.93)\end{array}$ & $\begin{array}{r}.092 \\
(1.96)\end{array}$ & $\begin{array}{l}-.011 \\
(-.74)\end{array}$ & .085 & .021 & 2.24 \\
\hline Metal Cans & $\begin{array}{r}.0160 \\
(3.52)\end{array}$ & $\begin{array}{r}.169 \\
(3.54)\end{array}$ & $\begin{array}{r}-.035 \\
(-1.96)\end{array}$ & .180 & .014 & 2.25 \\
\hline $\begin{array}{l}\text { Farm } \\
\text { Machinery }\end{array}$ & $\begin{array}{r}.0253 \\
(3.01)\end{array}$ & $\begin{array}{l}.004 \\
(.11)\end{array}$ & $\begin{array}{l}.004 \\
(.30)\end{array}$ & .076 & .024 & 2.03 \\
\hline $\begin{array}{l}\text { Motor } \\
\text { Vehicles }\end{array}$ & $\begin{array}{r}.0318 \\
(4.22)\end{array}$ & $\begin{array}{l}.004 \\
(.14)\end{array}$ & $\begin{array}{r}-.014 \\
(-1.42)\end{array}$ & .167 & .022 & 2.47 \\
\hline $\begin{array}{l}\text { Meat } \\
\text { Packing }\end{array}$ & $\begin{array}{l}.0036 \\
(.82)\end{array}$ & $\begin{array}{r}.162 \\
(1.63)\end{array}$ & $\begin{array}{r}.063 \\
(2.20)\end{array}$ & .083 & .012 & 2.17 \\
\hline Cigarettes & $\begin{array}{r}.0112 \\
(1.84)\end{array}$ & $\begin{array}{l}.020 \\
(.22)\end{array}$ & $\begin{array}{l}.002 \\
(.08)\end{array}$ & .031 & .018 & 2.53 \\
\hline $\begin{array}{l}\text { Ken's } \\
\text { Apparel }\end{array}$ & $\begin{array}{r}.0178 \\
(3.35)\end{array}$ & $\begin{array}{c}-.013 \\
(-.21)\end{array}$ & $\begin{array}{l}.012 \\
(.67)\end{array}$ & .095 & .016 & 2.13 \\
\hline Petroleum & $\begin{array}{r}.0221 \\
(5.76)\end{array}$ & $\begin{array}{r}.125 \\
(2.71)\end{array}$ & $\begin{array}{l}-.004 \\
(-.24)\end{array}$ & .265 & .014 & 2.02 \\
\hline Tires & $\begin{array}{r}.0099 \\
(1.45)\end{array}$ & $\begin{array}{l}.008 \\
(.11)\end{array}$ & $\begin{array}{r}-.052 \\
(-2.26)\end{array}$ & .063 & .023 & 2.25 \\
\hline
\end{tabular}


TABLE 4 -- Results by Industry for Employment Equation (19)

Sawmills

Slass

Containers

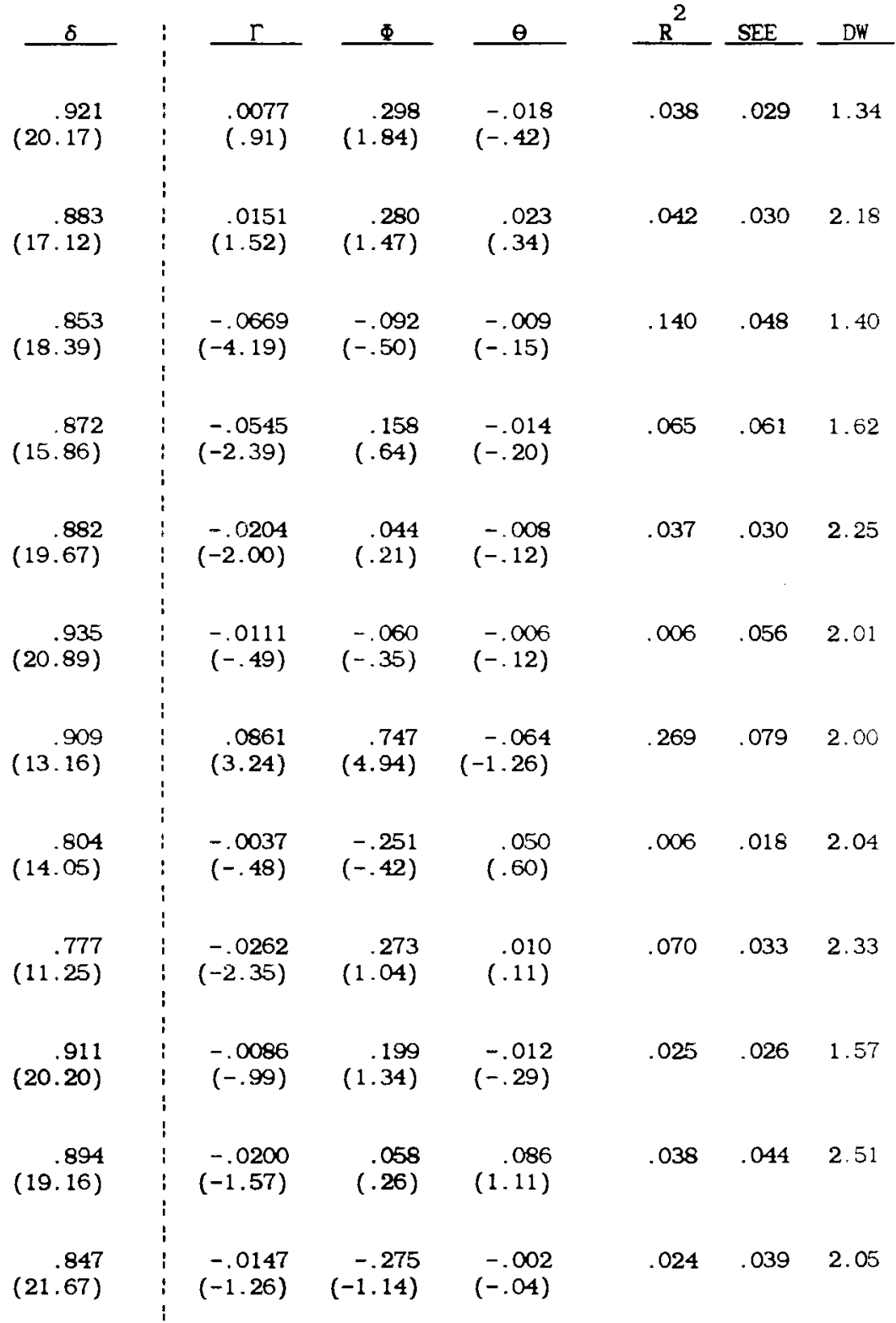

luminum

Ietal Cans

Tarm

Lachinery

lotor

Jehicles

Leat

Packing

Cigarettes

Len's

Apparel

Petroleum

Tires

$(-1.26) \quad(-1.14) \quad(-.04)$ 
Table 5 -- Estimated Employment Variability. Flexible Wages (L*) Versus Actual Contracts (L)

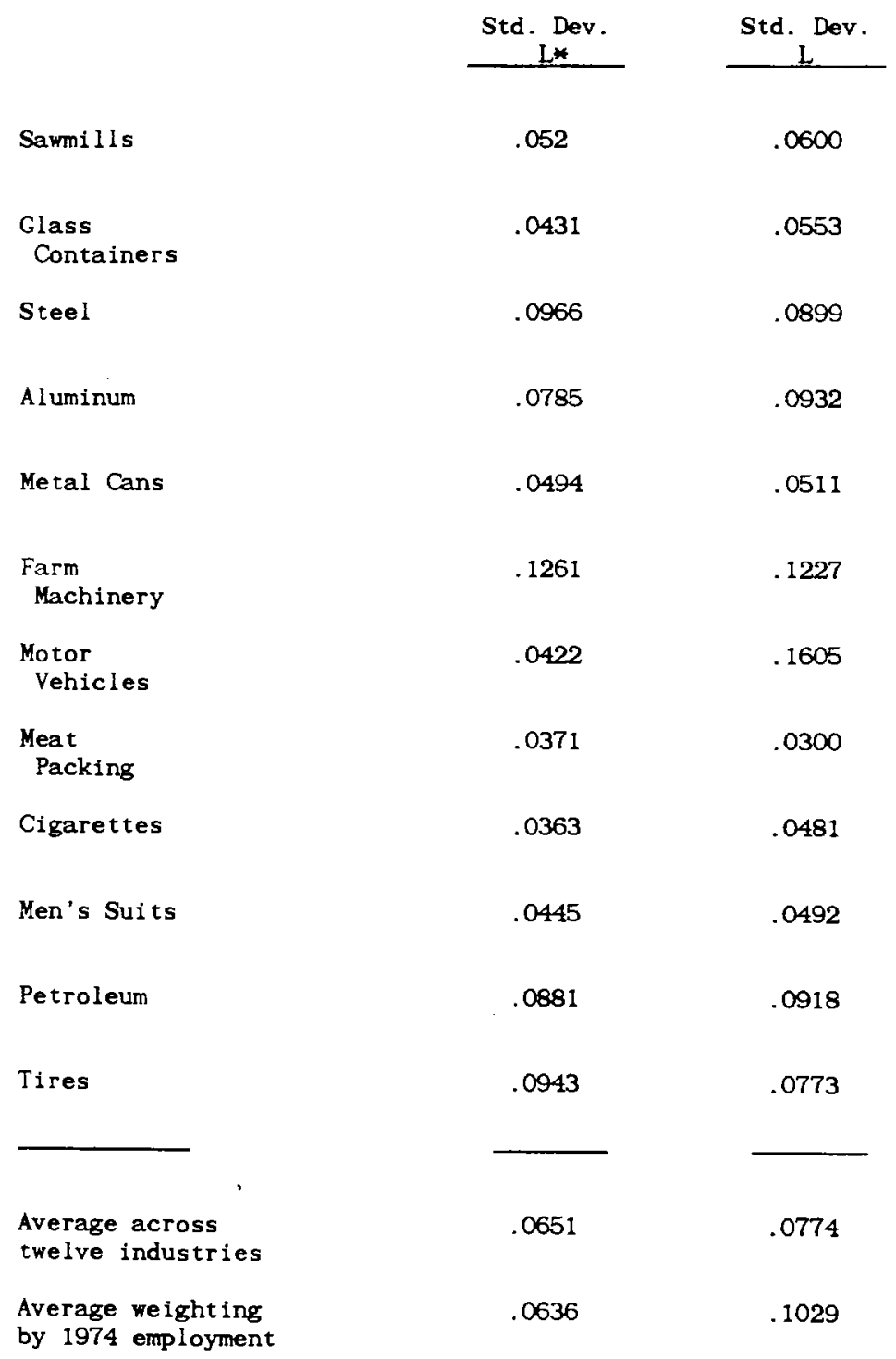


TABLE 6 -- Results by Industry for Wage Equation (21)

Sawmills

Glass

Containers

Steel

Aluminum

Metal Cans

Farm

Machinery

Motor

Vehicles

Meat

Packing

Cigaret tes

Men's

Appare 1

Petroleum

Tires

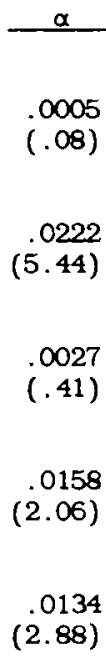

.0158
$(2.06)$

.0134

(2.88)

.0027

.0222
$(5.44)$

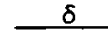

(18.64)

.869

(17.88)

.975

(33.64)

.937

(18.04)

.902

(17.96)

.817

(12.08)

.854

(12.72)

.961

(35.59)

.798

(12.03)

.866

$(17.62)$

$\begin{array}{rr}.093 & -.049 \\ (1.21) & (-1.98)\end{array}$

$\begin{array}{lr}.051 & -.037 \\ (.48) & (-1.34)\end{array}$

.186

(2.39)

.010
$(.37)$

$(.37)$$$
\text { (1.21) (-1.98) }
$$

$\begin{array}{ll}.095 & -.018 \\ (1.13) & (-.73)\end{array}$

(1.13) (-.73)

.0202

(2.50)

$.144-.040$

(1.55) $(-1.39)$

.0278

(3.86)

.010

(.20)

.014

(.78)

$-.039$

$-.007$

$(-.96) \quad(-.54)$

.0057

(1.38)

.053

(.25)

.089

(1.64)

.0107

(1.87)

$-.135$

$(-1.00)$

-.046
$(-1.01)$

.0148

(2.89)

$$
-.022
$$

$(-.25)$

.045

(1.83)

.0214
$(5.52)$

.092

$-.007$

(1.34) $(-.29)$

$(19.26)$

$(5.52)$

.932

(19.53)

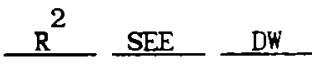

$.016 \quad .019 \quad 2.13$

$.260 \quad .012 \quad 2.33$

$.038 \quad .020 \quad 2.13$

$.059 \quad .021 \quad 2.32$

$.100 \quad .014 \quad 2.13$

$.058 \quad .023 \quad 1.93$

$.146 \quad .021 \quad 2.38$

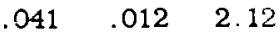

$.047 \quad .017 \quad 2.35$

$.097 \quad .015 \quad 2.02$

$.218 \quad .014 \quad 1.98$

$.078 \quad .022 \quad 2.17$ 